\title{
Paenibacillus gansuensis sp. nov., isolated from desert soil of Gansu Province in China
}

\author{
Correspondence \\ Chang-Jin Kim \\ changjin@kribb.re.kr
}

\author{
Jee-Min Lim, ${ }^{1}$ Che Ok Jeon, ${ }^{2}$ Jae-Chan Lee, ${ }^{1}$ Li-Hua Xu, ${ }^{3}$ \\ Cheng-Lin Jiang ${ }^{3}$ and Chang-Jin Kim ${ }^{1}$ \\ ${ }^{1}$ Korea Research Institute of Bioscience and Biotechnology, 52 Oeundong, Yusong, Daejeon \\ 305-333, Republic of Korea \\ 2Division of Applied Life Science, EB-NCRC, PMBBRC, Gyeongsang National University, \\ 660-701, Republic of Korea \\ ${ }^{3}$ Yunnan Institute of Microbiology, Yunnan University, Kunming, Yunnan, 650091, People's \\ Republic of China
}

\begin{abstract}
A Gram-positive, endospore-forming, rod-shaped bacterium, designated strain $\mathrm{B}^{2} 18^{\top}$, was isolated from a desert-soil sample from Gansu Province in China. The isolate was strictly aerobic and was motile by means of several flagella. The strain grew optimally at $35-40{ }^{\circ} \mathrm{C}$ and at $\mathrm{pH} 7 \cdot 0-7 \cdot 5$. The predominant fatty acids of strain $B 518^{\top}$ were anteiso- $\mathrm{C}_{15: 0}, \mathrm{C}_{16: 0}$, anteiso$C_{17: 0}$, iso- $C_{16: 0}$ and iso- $C_{15: 0}$. The $G+C$ content of the genomic DNA was 50 mol\% and the predominant quinone was MK-7. Comparative 16S rRNA gene sequence analyses showed that strain $\mathrm{B}^{2} 18^{\top}$ formed a distinct phyletic line within the genus Paenibacillus and was most closely related to Paenibacillus chitinolyticus IFO $15660^{\top}$, with a $16 \mathrm{~S}$ rRNA gene sequence similarity of $95 \cdot 8 \%$. The levels of $16 \mathrm{~S}$ rRNA gene sequence similarity with respect to other type strains of Paenibacillus species were below $95 \cdot 1 \%$. On the basis of the chemotaxonomic data and molecular properties, strain $\mathrm{B}^{518^{\top}}$ represents a novel species within the genus Paenibacillus, for which the name Paenibacillus gansuensis sp. nov. is proposed. The type strain is B518 ${ }^{\top}$ (=KCTC $3950^{\top}=$ DSM $16968^{\top}$ ).
\end{abstract}

The genus Paenibacillus was created from the group 3 bacilli on the basis of a 16S rRNA gene sequence analysis conducted by Ash et al. (1993). Since the description of the genus, species belonging to the genus Paenibacillus have been isolated from various ecological habitats, including warm springs (Saha et al., 2005), rice fields (Sánchez et al., 2005), alkaline soils (Yoon et al., 2005), petroleum-hydrocarboncontaminated sediment (Daane et al., 2002), the surface of sterilized seeds of garden peas (Šmerda et al., 2005), Antarctic sediments (Montes et al., 2004) and the phyllospheres and rhizospheres of trees (Rivas et al., 2005a, b; Lim et al., 2006). In this report, we describe the taxonomic characterization of a novel aerobic, mesophilic, Grampositive Paenibacillus species that produces an ellipsoidal terminal endospore in a swollen sporangium.

Strain $\mathrm{B} 518^{\mathrm{T}}$ was isolated from a desert-soil sample $(1000 \mathrm{~m}$ above sea level) collected in northwest China (Sunan

The GenBank/EMBL/DDBJ accession number for the $16 \mathrm{~S}$ rRNA gene sequence of strain B518 ${ }^{\top}$ is AY839866.

Transmission electron micrographs showing the morphology, cell wall and spore structures of strain $\mathrm{B} 18^{\mathrm{T}}$, and a neighbour-joining phylogenetic tree for strain $B 518^{\top}$ and related taxa are available as supplementary figures in IJSEM Online.
County, Gansu Province) by serial dilution plating on R2A agar (Difco) at $30^{\circ} \mathrm{C}$ for 3 days. Subcultivation was done on $\mathrm{R} 2 \mathrm{~A}$ agar at $35^{\circ} \mathrm{C}$ for $2-3$ days. Gram staining was performed using a bioMérieux Gram-stain kit according to the manufacturer's instructions. Cell morphology and motility were studied using phase-contrast microscopy and transmission electron microscopy (JEM-1010; JEOL) as described by Jeon et al. (2003, 2005). Endospores were stained according to the Schaeffer-Fulton method (Smibert \& Krieg, 1981). The physiological characteristics of strain $\mathrm{B} 518^{\mathrm{T}}$ were examined by growing the isolate on $\mathrm{R} 2 \mathrm{~A}$ medium. Growth was tested at different $\mathrm{pH}$ values $(6 \cdot 0-12 \cdot 0)$ and temperatures $\left(4-50{ }^{\circ} \mathrm{C}\right)$ on $\mathrm{R} 2 \mathrm{~A}$ broth. $\mathrm{R} 2 \mathrm{~A}$ broths with different $\mathrm{pH}$ values were prepared as described previously (Gomori, 1955). Oxidase activity was tested by assessing the oxidation of $1 \%(\mathrm{w} / \mathrm{v})$ tetramethyl- $p$ phenylenediamine (Merck), and catalase activity was evaluated by assessing the production of $\mathrm{O}_{2}$ bubbles in a $3 \%(\mathrm{v} / \mathrm{v})$ aqueous $\mathrm{H}_{2} \mathrm{O}_{2}$ solution. The hydrolysis of compounds was checked on R2A agar according to methods described previously (Lanyi, 1987; Smibert \& Krieg, 1994). Nitrate reduction was performed according to the method of Lanyi (1987), and acid production from carbohydrates was tested as described by Leifson (1963). When grown on $\mathrm{R} 2 \mathrm{~A}$ agar at $35^{\circ} \mathrm{C}$ for 2 days, strain $\mathrm{B} 518^{\mathrm{T}}$ formed pale 
yellow, glistening, translucent, slightly sticky, irregular and slightly raised colonies. Growth was observed at temperatures between 10 and $45^{\circ} \mathrm{C}$; optimum growth occurred at $35-40{ }^{\circ} \mathrm{C}$ and $\mathrm{pH} 7 \cdot 0-7 \cdot 5$. The cells of the isolate were motile rods $(0.7-0.9 \mu \mathrm{m}$ wide and $1.7-2.4 \mu \mathrm{m}$ long) possessing several flagella (see Supplementary Fig. S1a available in IJSEM Online). The cells of strain $\mathrm{B} 518^{\mathrm{T}}$ were Gram-positive, oxidase-negative, catalase-negative, and did not reduce nitrate to nitrite. The isolate produced an ellipsoidal terminal endospore in a swollen sporangium. Anaerobic growth was not observed under anaerobic conditions for 5 days at $35^{\circ} \mathrm{C}$ on $\mathrm{R} 2 \mathrm{~A}$ agar.

Analysis of the fatty acid methyl esters was performed according to the instructions of the Microbial Identification System (MIDI; Microbial ID). Analyses of peptidoglycan and isoprenoid quinones were carried out using the methods described by Komagata \& Suzuki (1987). The $\mathrm{G}+\mathrm{C}$ content of the genomic DNA of strain $\mathrm{B} 518^{\mathrm{T}}$ was determined, using HPLC apparatus fitted with a reversedphase column (GROM-SIL 100 ODS-2FE; GROM), according to the method of Tamaoka \& Komagata (1984). The major respiratory lipoquinone of strain $\mathrm{B} 518^{\mathrm{T}}$ was MK-7. The fatty acid profile of the strain showed a predominance of saturated fatty acids such as anteiso- $\mathrm{C}_{15: 0}(48 \cdot 7 \%), \mathrm{C}_{16: 0}$ $(10 \cdot 1 \%)$, anteiso- $\mathrm{C}_{17: 0}(9 \cdot 6 \%)$, iso- $\mathrm{C}_{16: 0}(9 \cdot 5 \%)$ and iso$\mathrm{C}_{15: 0}(9 \cdot 1 \%)$. Similar fatty acid profiles have also been reported for type strains of the genus Paenibacillus (Table 1). Cell-wall peptidoglycan could not be extracted from strain $\mathrm{B} 518^{\mathrm{T}}$, which was confirmed by several reexaminations and analysis by another institute (Deutsche

Table 1. Cellular fatty acid content of strain $B 518^{\top}$ and related taxa

Taxa: 1, strain $\mathrm{B} 518^{\mathrm{T}} ; 2$, P. chitinolyticus IFO $15660^{\mathrm{T}}$ (Lee et al., 2004); 3, P. daejeonensis AP-20 ${ }^{\mathrm{T}}$ (Lee et al., 2002); 4, Paenibacillus ehimensis KCTC $3748^{\mathrm{T}}$ (Lee et al., 2004); 5, Paenibacillus polymyxa DSM $36^{\mathrm{T}}$ (Enright et al., 2003; Kuroshima et al., 1996). Data are expressed as percentages of total fatty acids. Fatty acids representing less than $0 \cdot 5 \%$ are not included.

\begin{tabular}{|lrcccr|}
\hline Fatty acid & $\mathbf{1}$ & $\mathbf{2}$ & $\mathbf{3}$ & $\mathbf{4}$ & $\mathbf{5}$ \\
\hline Saturated & & & & & \\
$\mathrm{C}_{14: 0}$ & $1 \cdot 5$ & - & $2 \cdot 8$ & - & $2 \cdot 9$ \\
$\mathrm{C}_{15: 0}$ & $1 \cdot 0$ & - & $15 \cdot 9$ & - & $0 \cdot 8$ \\
$\mathrm{C}_{16: 0}$ & $10 \cdot 1$ & $6 \cdot 9$ & $14 \cdot 3$ & $7 \cdot 1$ & $15 \cdot 6$ \\
iso-C $14: 0$ & $1 \cdot 5$ & - & $2 \cdot 4$ & - & $2 \cdot 4$ \\
iso- $\mathrm{C}_{15: 0}$ & $9 \cdot 1$ & $3 \cdot 6$ & $7 \cdot 2$ & $8 \cdot 1$ & $9 \cdot 7$ \\
iso- $\mathrm{C}_{16: 0}$ & $9 \cdot 5$ & $8 \cdot 4$ & $10 \cdot 2$ & $8 \cdot 6$ & $8 \cdot 6$ \\
iso- $\mathrm{C}_{17: 0}$ & $6 \cdot 0$ & $2 \cdot 0$ & $2 \cdot 5$ & $3 \cdot 3$ & $8 \cdot 5$ \\
anteiso-C $15: 0$ & $48 \cdot 7$ & $58 \cdot 7$ & $36 \cdot 4$ & $52 \cdot 9$ & $41 \cdot 3$ \\
anteiso-C $17: 0$ & $9 \cdot 6$ & $7 \cdot 3$ & $2 \cdot 7$ & $8 \cdot 0$ & $8 \cdot 4$ \\
Others & & & & & \\
$\mathrm{C}_{16: 1} \omega 11 c$ & $0 \cdot 8$ & - & $2 \cdot 6$ & $5 \cdot 2$ & $1 \cdot 5$ \\
iso- $\mathrm{C}_{17: 0} \omega 10 c$ & $0 \cdot 9$ & - & - & - & - \\
\hline
\end{tabular}

Sammlung von Mikroorganismen und Zellkulturen, Braunschweig, Germany). However, examination of thin sections using transmission electron microscopy revealed the presence of a typical single, thick, Gram-positive cellwall ultrastructure and a typical spore structure (see Supplementary Fig. S1b, c in IJSEM Online). The G+C content of the genomic DNA of strain $\mathrm{B} 518^{\mathrm{T}}$ was $50 \mathrm{~mol} \%$. In Table 2, the typical phenotypic characteristics of strain $\mathrm{B} 518^{\mathrm{T}}$ are summarized and compared with those of the type strains of closely related taxa. Members of the genus Paenibacillus produce an ellipsoidal, terminal endospore in a swollen sporangium, possess anteiso- $\mathrm{C}_{15: 0}$ as the major fatty acid and have DNA G $+\mathrm{C}$ contents in the range 39-55\% (Shida et al., 1997; Montes et al., 2004; Takeda et al., 2005). Strain $\mathrm{B} 518^{\mathrm{T}}$ also possesses these phenotypic characteristics typical of the genus Paenibacillus.

The sequencing and assembly of the $16 \mathrm{~S}$ rRNA gene sequence were carried out as described by Bakermans \& Madsen (2002). The sequence of strain $\mathrm{B} 518^{\mathrm{T}}$ was compared with 16S rRNA gene sequences available in GenBank by using the BLAST program (http://www.ncbi.nlm.nih.gov/ blast/) to determine the approximate phylogenetic affiliation, and was aligned with close relatives by using CLUSTAL $\mathrm{W}$ software (Thompson et al., 1994). Phylogenetic trees were constructed using three different methods, namely the neighbour-joining, maximum-likelihood and maximumparsimony algorithms available in PHYLIP, version 3.6

Table 2. Characteristics of strain $B 518^{\top}$ and some related taxa

Taxa: 1, strain $\mathrm{B} 518^{\mathrm{T}} ; 2$, P. chitinolyticus IFO $15660^{\mathrm{T}}$ (Lee et al., 2004); 3, P. polymyxa DSM $36^{\mathrm{T}}$ (Enright et al., 2003; Kuroshima et al., 1996); 4, P. daejeonensis AP-20 (Lee et al., 2002); 5, P. ehimensis KCTC $3748^{\mathrm{T}}$ (Lee et al., 2004). Symbols: +, positive; -, negative; $\mathrm{V}$, variable; ND, not determined.

\begin{tabular}{|lccccc|}
\hline Characteristic & $\mathbf{1}$ & $\mathbf{2}$ & $\mathbf{3}$ & $\mathbf{4}$ & $\mathbf{5}$ \\
\hline Anaerobic growth & - & - & + & $\mathrm{ND}$ & - \\
Oxidase & - & $\mathrm{V}$ & - & + & + \\
Catalase & - & + & + & + & $\mathrm{ND}$ \\
Nitrate reduction & - & + & $\mathrm{V}$ & + & + \\
Motility & + & + & $\mathrm{ND}$ & + & $\mathrm{ND}$ \\
Growth at $50{ }^{\circ} \mathrm{C}$ & - & - & - & $\mathrm{ND}$ & + \\
Acid production from: & & & & & \\
$\quad$ Arabinose & + & - & - & $\mathrm{ND}$ & + \\
$\quad$ Glucose & + & + & $\mathrm{ND}$ & $\mathrm{ND}$ & + \\
$\quad$ Lactose & + & $\mathrm{ND}$ & + & + & $\mathrm{ND}$ \\
$\quad$ Mannitol & - & - & + & + & + \\
$\quad$ Xylose & + & - & + & $\mathrm{ND}$ & + \\
Hydrolysis of: & & & & & \\
$\quad$ Aesculin & + & $\mathrm{ND}$ & + & + & $\mathrm{ND}$ \\
$\quad$ Casein & + & + & + & $\mathrm{ND}$ & $\mathrm{V}$ \\
$\quad$ Starch & - & - & + & $\mathrm{ND}$ & + \\
DNA G+C content $(\mathrm{mol} \%)$ & 50 & $51-53$ & $43-46$ & 53 & $52-53$ \\
\end{tabular}




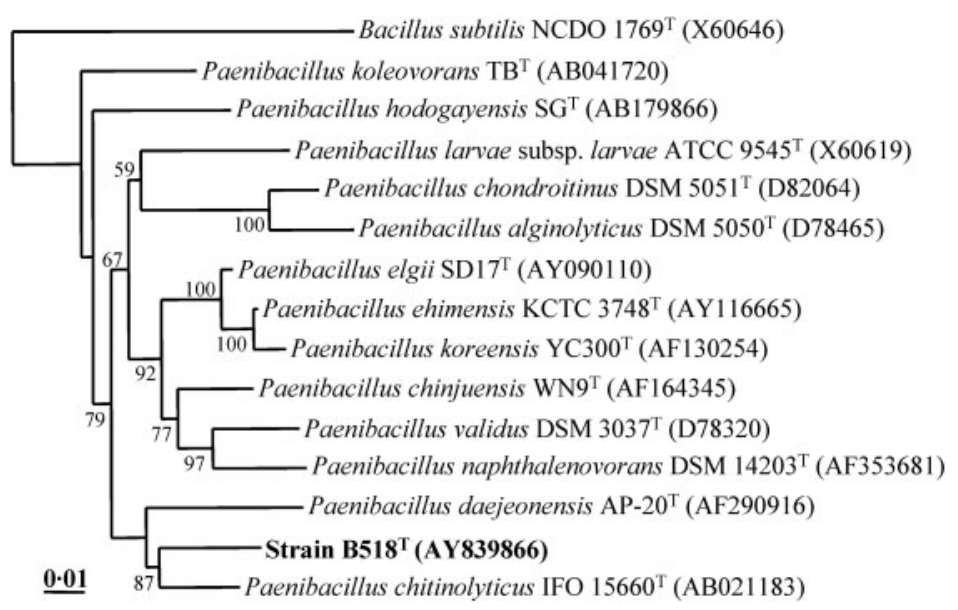

Fig. 1. Neighbour-joining tree, based on 16S rRNA gene sequences, showing phylogenetic relationships of strain $B 518^{\top}$ and related taxa. Bootstrap values (percentages of 1000 replicates) are shown where greater than $50 \%$. Bacillus subtilis NCDO $1769^{\top}$ was used as an outgroup. Bar, 0.01 changes per nucleotide position.
(Felsenstein, 2002). By using the FASTA3 program in EBI, 16S rRNA gene sequence comparisons for similarity calculations were made between the novel strain and related members of the genus Paenibacillus. A bootstrap analysis was performed using the algorithm of the Kimura two-parameter model (Kimura, 1980) of the neighbour-joining method in the PHYLIP package. An almost-complete 16S rRNA gene sequence $(1529 \mathrm{nt})$ of strain $\mathrm{B} 518^{\mathrm{T}}$ was obtained, and a phylogenetic analysis based on 16S rRNA gene sequences showed that strain $\mathrm{B} 518^{\mathrm{T}}$ formed a distinct cluster with Paenibacillus chitinolyticus IFO $15660^{\mathrm{T}}$ and Paenibacillus daejeonensis KCTC $3745^{\mathrm{T}}$ (see Fig. 1; an extended version of this tree is available as Supplementary Fig. S2 in IJSEM Online). The topologies of phylogenetic trees built using the maximum-likelihood and maximum-parsimony algorithms also supported the notion that the isolate belongs to the genus Paenibacillus (data not shown). The 16S rRNA gene sequence of strain $\mathrm{B} 518^{\mathrm{T}}$ also contained two signature sequences found in most Paenibacillus species, i.e. PAEN 862F (5'-TCGATACCCTTGGTGCCGAAGT-3') and PAEN 515F (5'-GAGTAACTGCTCTCGGAATGACGGTACTTGAGAAGAAAGCCCC-3') (Saha et al., 2005). Comparative 16S rRNA gene sequence analyses showed that the isolate was most closely related to $P$. chitinolyticus IFO $15660^{\mathrm{T}}$, having a similarity of $95 \cdot 8 \%$. Sequence similarities to other members included in the phylogenetic analysis were below $95 \cdot 1 \%$. Thus, on the basis of the physiological, biochemical and phylogenetic properties of strain $\mathrm{B} 518^{\mathrm{T}}$, this isolate represents a novel species within the genus Paenibacillus, for which the name Paenibacillus gansuensis sp. nov. is proposed.

\section{Description of Paenibacillus gansuensis sp. nov.}

Paenibacillus gansuensis (gan.su.en'sis. N.L. masc. adj. gansuensis belonging to Gansu, from where the type strain was isolated).

Cells are Gram-positive rods, $0 \cdot 7-0.9 \mu \mathrm{m}$ wide and $1 \cdot 7-2 \cdot 4 \mu \mathrm{m}$ long at $35^{\circ} \mathrm{C}$ on R2A agar. Motile by means of several flagella. Colonies are glistening, translucent, semi-sticky, irregular, slightly raised and pale yellow on R2A agar. Growth occurs at $10-45^{\circ} \mathrm{C}$ (optimum, $35-40{ }^{\circ} \mathrm{C}$ ). Nitrate is not reduced to nitrite. Catalase- and oxidasenegative. Aesculin, casein and Tween 80 are hydrolysed. Hypoxanthine, tyrosine, starch and xanthine are not hydrolysed. Acids are produced from D-glucose, D-fructose, D-ribose, D-xylose, lactose, D-trehalose, maltose, L-arabinose, D-raffinose, D-mannose, myo-inositol, glycerol, sucrose, melibiose and salicin, but not from D-mannitol, adonitol or arbutin. The major isoprenoid quinone is MK-7. The major fatty acids are anteiso- $\mathrm{C}_{15: 0}, \mathrm{C}_{16: 0}$, anteiso- $\mathrm{C}_{17: 0}$, iso- $\mathrm{C}_{16: 0}$ and iso- $\mathrm{C}_{15: 0}$. The DNA $\mathrm{G}+\mathrm{C}$ content is $50 \mathrm{~mol} \%$ (HPLC).

The type strain, B518 ${ }^{\mathrm{T}}\left(=\mathrm{KCTC} 3950^{\mathrm{T}}=\mathrm{DSM} 16968^{\mathrm{T}}\right)$, was isolated from a desert-soil sample from Gansu Province in China.

\section{Acknowledgements}

This work was supported by the 21C Frontier Microbial Genomics and Application Center Program, Ministry of Science \& Technology, Republic of Korea.

\section{References}

Ash, C., Priest, F. G. \& Collins, M. D. (1993). Molecular identification of rRNA group 3 bacilli (Ash, Farrow, Wallbanks and Collins) using a PCR probe test. Proposal for the creation of a new genus Paenibacillus. Antonie van Leeuwenhoek 64, 253-260.

Bakermans, C. \& Madsen, E. L. (2002). Diversity of $16 \mathrm{~S}$ rDNA and naphthalene dioxygenase genes from coal-tar-waste-contaminated aquifer waters. Microb Ecol 44, 95-106.

Daane, L. L., Harjono, I., Barns, S. M., Launen, L. A., Palleroni, N. J. \& Haggblom, M. M. (2002). PAH-degradation by Paenibacillus spp. and description of Paenibacillus naphthalenovorans sp. nov., a naphthalene-degrading bacterium from the rhizosphere of salt marsh plants. Int J Syst Evol Microbiol 52, 131-139.

Enright, M. R., Mclnerney, J. O. \& Griffin, C. T. (2003). Characterization of endospore-forming bacteria associated with entomopathogenic nematodes, Heterorhabditis spp., and description of Paenibacillus nematophilus sp. nov. Int J Syst Evol Microbiol 53, $435-441$. 
Felsenstein, J. (2002). PHYLIP (phylogeny inference package), version 3.6a. Distributed by the author. Department of Genome Sciences, University of Washington, Seattle, USA.

Gomori, G. (1955). Preparation of buffers for use in enzyme studies. Methods Enzymol 1, 138-146.

Jeon, C. O., Lee, D. S. \& Park, J. M. (2003). Microbial communities in activated sludge performing enhanced biological phosphorus removal in a sequencing batch reactor. Water Res 37, 2195-2205.

Jeon, C. O., Lim, J. M., Lee, J. M., Xu, L. H., Jiang, C. L. \& Kim, C. J. (2005). Reclassification of Bacillus haloalkaliphilus Fritze 1996 as Alkalibacillus haloalkaliphilus gen. nov., comb. nov. and the description of Alkalibacillus salilacus sp. nov., a novel halophilic bacterium isolated from a salt lake in China. Int J Syst Evol Microbiol 55, 743-746.

Kimura, M. (1980). A simple method for estimating evolutionary rates of base substitutions through comparative studies of nucleotide sequences. J Mol Evol 16, 111-120.

Komagata, K. \& Suzuki, K. (1987). Lipid and cell-wall analysis in bacterial systematics. Methods Microbiol 19, 161-208.

Kuroshima, K.-I., Sakane, T., Takata, R. \& Yokota, A. (1996). Bacillus ehimensis sp. nov. and Bacillus chitinolyticus sp. nov., new chitinolytic members of the genus Bacillus. Int J Syst Bacteriol 46, 76-80.

Lanyi, B. (1987). Classical and rapid identification methods for medically important bacteria. Methods Microbiol 19, 1-67.

Lee, J.-S., Lee, K. C., Chang, Y.-H., Hong, S. G., Oh, H. W., Pyun, Y.-R. \& Bae, K. S. (2002). Paenibacillus daejeonensis sp. nov., a novel alkaliphilic bacterium from soil. Int J Syst Evol Microbiol 52, 2107-2111.

Lee, J.-S., Pyun, Y.-R. \& Bae, K. S. (2004). Transfer of Bacillus ehimensis and Bacillus chitinolyticus to the genus Paenibacillus with emended descriptions of Paenibacillus ehimensis comb. nov. and Paenibacillus chitinolyticus comb. nov. Int J Syst Evol Microbiol 54, 929-933.

Leifson, E. (1963). Determination of carbohydrate metabolism of marine bacteria. J Bacteriol 85, 1183-1184.

Lim, J.-M., Jeon, C. O., Lee, J.-C., Ju, Y. J., Park, D.-J. \& Kim, C.-J. (2006). Bacillus koreensis sp. nov., a spore-forming bacterium, isolated from the vicinity of willow roots in Korea. Int J Syst Evol Microbiol 56, 59-63.

Montes, M. J., Mercade, E., Bozal, N. \& Guinea, J. (2004). Paenibacillus antarcticus sp. nov., a novel psychrotolerant organism from the Antarctic environment. Int J Syst Evol Microbiol 54, 1521-1526.

Rivas, R., Mateos, P. F., Martinez-Molina, E. \& Velazquez, E. (2005a). Paenibacillus phyllosphaerae sp. nov., a xylanolytic bacterium isolated from the phyllosphere of Phoenix dactylifera. Int J Syst Evol Microbiol 55, 743-746.
Rivas, R., Gutierrez, C., Abril, A., Mateos, P. F., Martinez-Molina, E., Ventosa, A. \& Velazquez, E. (2005b). Paenibacillus rhizosphaerae sp. nov., isolated from the rhizosphere of Cicer arietinum. Int J Syst Evol Microbiol 55, 1305-1309.

Saha, P., Mondal, A. K., Mayilraj, S., Krishnamurthi, S., Bhattacharya, A. \& Chakrabarti, T. (2005). Paenibacillus assamensis sp. nov., a novel bacterium isolated from a warm spring in Assam, India. Int J Syst Evol Microbiol 55, 2577-2581.

Sánchez, M. M., Fritze, D., Blanco, A., Spröer, C., Tindall, B. J., Schumann, P., Kroppenstedt, R. M., Diaz, P. \& Pastor, F. I. (2005). Paenibacillus barcinonensis sp. nov., a xylanase-producing bacterium isolated from a rice field in the Ebro River delta. Int J Syst Evol Microbiol 55, 935-939.

Shida, O., Takagi, H., Kadowaki, K., Nakamura, L. K. \& Komagata, K. (1997). Transfer of Bacillus alginolyticus, Bacillus chondroitinus, Bacillus curdlanolyticus, Bacillus glucanolyticus, Bacillus kobensis, and Bacillus thiaminolyticus to the genus Paenibacillus and emended description of the genus Paenibacillus. Int J Syst Bacteriol 47, 289-298.

Šmerda, J., Sedláček, I., Páčová, Z., Durnová, E., Smíškova, A. \& Havel, L. (2005). Paenibacillus mendelii sp. nov., from surfacesterilized seeds of Pisum sativum L. Int J Syst Evol Microbiol 55, 2351-2354.

Smibert, R. M. \& Krieg, N. R. (1981). General characterization. In Manual of Methods for General Microbiology, pp. 409-443. Edited by P. Gerhardt, R. G. E. Murray, R. N. Costilow, E. W. Nester, W. A. Wood, N. R. Krieg \& G. B. Phillips. Washington, DC: American Society for Microbiology.

Smibert, R. M. \& Krieg, N. R. (1994). Phenotypic characterization. In Methods for General and Molecular Bacteriology, pp. 607-654. Edited by P. Gerhardt. Washington, DC: American Society for Microbiology.

Takeda, M., Suzuki, I. \& Koizumi, J. (2005). Paenibacillus hodogayensis sp. nov., capable of degrading the polysaccharide produced by Sphaerotilus natans. Int J Syst Evol Microbiol 55, 737-741.

Tamaoka, J. \& Komagata, K. (1984). Determination of DNA base composition by reverse-phase high-performance liquid chromatography. FEMS Microbiol Lett 25, 125-128.

Thompson, J. D., Higgins, D. G. \& Gibson, T. J. (1994). CLUSTAL_W: improving the sensitivity of progressive multiple sequence alignment through sequence weighting, position-specific gap penalties and weight matrix choice. Nucleic Acids Res 22, 4673-4680.

Yoon, J. H., Kang, S. J., Yeo, S. H. \& Oh, T. K. (2005). Paenibacillus alkaliterrae sp. nov., isolated from an alkaline soil in Korea. Int J Syst Evol Microbiol 55, 935-939. 